WellBeing International

WBI Studies Repository

1986

\title{
Humans and Other Animals: A Biological and Ethical Perspective
}

Ashley Montagu

Follow this and additional works at: https://www.wellbeingintlstudiesrepository.org/acwp_sata

Part of the Animal Studies Commons, Ethics and Political Philosophy Commons, and the Other Anthropology Commons

\section{Recommended Citation}

Montagu, A. (1986). Humans and other animals: A biological and ethical perspective. In M.W. Fox \& L.D. Mickley (Eds.), Advances in animal welfare science 1986/87 (pp. 165-177). Washington, DC: The Humane Society of the United States.

This material is brought to you for free and open access by WellBeing International. It has been accepted for inclusion by an authorized administrator of the WBI Studies Repository. For more information, please contact wbisr-info@wellbeingintl.org.

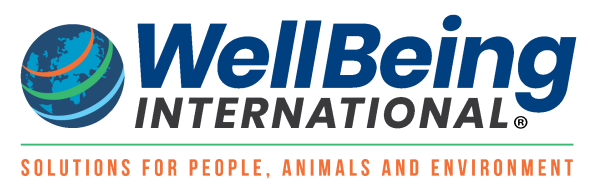




\title{
HUMANS AND OTHER ANIMALS: A BIOLOGICAL AND eTHICAl PERSPECTIVE ${ }^{1}$
}

\author{
Ashley Montagu ${ }^{2}$ \\ Dedicated to the Memory of Dian Fossey (1933-1986) \\ Naturalist, Protector, and Friend of the Virunga Gorillas-
}

The modern science of ecology is showing us that the fate of the Earth and of humanity are inextricably connected. This is as much a biological fact as it is a spiritual condition, from which arise the ethical principles and moral sensibility to live in respectful harmony with the rest of creation.

(From the Preamble to the Program of the International Network for Religion and Animals, 1986.)

The first thing to be said about our title is that all humans are animals. Our biological kinship with the whole of animated nature, to use an oldfashioned phrase, in one Great Chain of Being should be unequivocally clear. In this connexion should also be included our intimate relationship to the world of inanimate nature, precisely because it is inanimate, for it speaks to us in a voice no less appealing and meaningful than that other, of animate nature. In our Father's house, we are members of one family, but in its mansions we are guests in common with all its other inhabitants, neither superior nor inferior, but members of an extended family, a kingdom of animate and inanimate nature comprising several millions of variegated species, and sustaining a physical environment the most wonderful and beautiful to behold. As an anatomist, a biological anthropologist, and social biologist, I have learned that we are made of the same essential materials as are all other animals, that ultimately, indeed, we are constructed of the same stuff as is our world, and that our kinship is with the whole of nature, that we are guests upon this earth, and should conduct ourselves accordingly, with sensitivity, thoughtfulness, reverence, enjoyment, and gratitude.

Gradually we are beginning to understand that it is upon the clear recognition of our biological continuity and community with the whole of nature that our very survival, that the survival of this marvelous world, depends.

Whether we choose to view nature and evolution as God's way of creation, or whether we dispense with the idea of a supreme being as a creation myth common to most known peoples, the fact of evolution is clear, and 
certainly it is the best authenticated explanation of the origins and development of the vast variety of animate and inanimate forms on this earth (Montagu 1984). Evolution is just another word for development, or the maximization of the improbable, and development comes about largely as a consequence of the adaptive "responses" as it were, which the organism makes to the challenges of the environment. Such responses do not imply any conscious decision on the part of the organism, but rather the "selection," for the most part, by the environment of those organisms possessing the variations that most successfully, that is, adaptively, fit the organism to the challenges of the environment. Of all the improbable species that have come into being in this manner, humankind is in many ways the most improbable, Homo sapiens. Oscar Wilde, has not altogether unjustly described the name that Linnaeus, in 1758, bestowed upon our species, as the most oafishly arrogant, prematurely self-serving description ever perpetrated. Certainly it is true that the sapience, the wisdom, is there as a potentiality, but there can be no doubt that by the measure of his performance in human relations, and to the remainder of nature over the last twelve thousand years, in civilized societies, at least, he deserves no better appellation than Homo sap. A confused mindedness which has come about largely as a result of the unique evolutionary history of our species. Not only are we the only species that is able to weep, that is, to cry with tears, but we are also the only species able to laugh vocally. It is true that humankind has more to weep and also to laugh about than any other species. Perhaps that is why we are able to do so (Montagu 1960a, b). Be that as it may, it turns out that these two human traits constitute a saving grace in a rather cubistically dilapidated human landscape. To weep and to laugh are adaptive traits of supreme value, for without them sympathy, compassion, and self-criticism would scarcely be possible. A species so endowed cannot ever be without hope.

The trait, however, which beyond all others distinguishes humans from all other creatures is educability. It is our defining and outstanding characteristic as a species.

We have few, if any, remnants of instincts, and whatever we do as human beings, as buman beings, we have to learn from other human beings. We share, of course, innumerable traits, both physical and behavioral, with other animals, but everything we come to know and do as buman beings, those things which render us distinctively unlike any other animal, we must learn under the tutelage of other human beings. For example, we are all born with the capacity, that is, the potentiality for speech, a trait which is unique to our species, but no one of us would ever speak were it not for the teaching, the training, we receive from others, that capacity would never develop into an ability. A capacity is a potentiality, an ability is a trained capacity. Thinking as potentiality is a capacity, but how we come to think will depend largely upon the conditioning to which we are exposed. It is because of those capacities that to be born human is to be in danger, for by virtue of our unparalleled educability we are capable of learning more 
unsound things as well as more sound ones than any other creature: and when one puts the two together, one doesn't get intelligence, what one gets is confusion, a state in which most of our species now more than ever dangerously flounders.

In our technological age we have very nearly perfected the knack of arranging the world so that we can muddle through it on the basis of pseudological rationalizations built on unexamined and unanalyzed habits of stereotyping. The greater our progress in the development of technological substitutes for thought, the more spiritually illiterate we become. For quite some time now we have been flattering ourselves that we can make machines that think like human beings, without ever having grasped the fact that for a much longer time we have been turning out human beings who think like machines, that is, who don't think at all.

What we teach in our schools is what to think, not bow to think. Jane Taylor (1783-1824), the gifted young English author, early in the nineteenth century, put it very well:

Though man a thinking being is defined,

Few use the grand prerogative of mind,

How think justly of the thinking few;

How many never think, who think they do!

Alas, the proportion of people who think today is probably much less than in Jane Taylor's day, for in our own time we are besieged with such institutions as commercial television, which has appropriately been called "the lobotomy box," or "the chewing gum of the mind," which, as is well known, is designed to provide formula fodder, accompanied by a mindless excess of shockwaves, for what is generally known in the industry as "the lowest common denominator." Children now spend more time watching the programs and commercials than they spend in school, with the result that they have been largely robbed of their childhood. The few programs that could be described as good make it abundantly clear what a marvelous medium television could be for a genuinely humane education and enlightenment without slighting entertainment one bit.

Our schools and colleges have become institutions, to a far larger extent than we realize, for the training in an incapacity to think, and in the ability, with the aid of ritual incantation, to compartmentalize incompatible ideas without the slightest discomfort, and, indeed, to grow quite comfortable with the disparity between what one solemnly declares one believes, and the very contrary of what one does in practice.

Early on we learn to engorge large quantities of rote remembered facts, and to disgorge them at ceremonial occasions dubbed "examinations" when after those who have displayed the greatest disgorgative capacities are graded the brightest and the best, and are the most highly rewarded. We go on from schools to colleges and universities, which have mostly come to be 
regarded as job-qualifying institutions, where we take A.B. degrees, M.A. degrees, and doctor's degrees, dying in the process both spiritually and intellectually by degrees.

In such a world, the mark of a truly educated person is one who has overcome the deficiencies of the educational system, one who has become an independent thinker, a questioner of the obvious, and who is not only able to use his mind as a fine instrument of precision, but also who is able to feel for others that sense of involvement and sympathy which would make the whole world kin. I speak here of love, for knowledge is not enough. It is loving kindness that must be joined to knowledge and to cleverness.

I am reminded here of those charmingly apposite verses by Dame Elizabeth Wordsworth (1840-1932), the first Principal of Lady Margaret Hall, at Oxford, entitled "The Good and the Clever":

If all the good people were clever, And all the clever people were good, The World would be better than ever We thought that it possibly could. But somehow 'tis seldom or never, The two hit it off as they should, The good are so harsh to the clever, The clever are so rude to the good! So friends let it be our endeavour To make each by each understood; For few can be so good like the clever, Or clever so well as the good.

Goodness, I shall hold, in its own way is as rational as cleverness, if not more so. Goodness, love, lovingkindness, are all words for the same thing, best resumed in the one word, "love." But what is love? It is a question like that other which Pontius Pilate did not stay to answer, that most people have asked, and equally have not done well for an answer. Corinthians 13 is very good, indeed, on the matter, but even better is George Chapman (1559-1634), poet, playwright, translator of Homer into English, and friend of Ben Johnson. In his play, All Fooles, acted in 1599, in the first scene of the first act, Chapman makes his hero Valerio break forth into the following paean:

I tell thee Love is Nature's second sun, Causing a spring of virtues where he shines; And as without the sun, the world's great eye, All colours, beauties, both of Art and Nature, Are given in vain to men, so without love All beauties bred in women are in vain, All virtues born in men lies buried, For love informs them as the sun doth colours, 
And as the sun, reflecting his warm beams

Against the earth, begets all fruits and flowers;

So love, fair shining in the inward man,

Brings forth in him the honourable fruits

Of valour, wit, virtue and haughty thoughts,

Brave resolution, and divine discourse:

Oh, 'tis the Paradise, the heaven of earth.

That is not bad for 1599 or any other time. It is, in fact, the soundest description of the role of love in human development with which I, as a student of human development am acquainted, and the most memorable.

From the biological point of view, love can be described as behavior designed to confer survival benefits in a creatively enlarging manner upon the other. Spelled out, this means that by your behavior you not only enable the other to live, but to live more fully fulfilled than they would otherwise have been. It means that love is the demonstrative communication to the other of your profound involvement in their welfare, such that you provide them with all the encouragements, stimulation, support, and succor that they require for healthy growth and fulfillment of their potentialities, the communication that you will never commit the supreme treason of letting them down when they are in need of you, that they can depend upon you always standing by ministering to their needs. For becoming what? What you are being to them. That is love, and it has never been better said than by George Chapman.

The important thing for us to understand is that our love must extend to all and every part of nature, and not be limited to our own kind. We have seen the effect of such limitations in the cruel denial of their human rights to whole peoples, as in the case of "The Final Solution" of the Nazis, resulting in coldblooded systematic murder of six million Jews, not to mention the millions of members of other miscalled "races," while the civilized world stood by and deliberately closed its eyes (Gilbert 1981, 1986; Ross 1980; Wyman 1984, 1985). The whole concept of "race" is a myth and a fraud, nevertheless it is subscribed to and acted upon by millions of people throughout the civilized world, not least to this day, in the United States of America (Montagu 1974).

As for the civilized world, I am reminded of Mr. Gandhi who, when asked by an American reporter what he thought of Western civilization, mused for a bit, and then replied, "You know, I don't think it would be such a bad idea."

And speaking of racism, it should be pointed out that the attitudes of many people towards animals is a kind of racism, that is, in the belief that human beings are superior to animals, that animals are a lower order of being, subordinate to and subject to the whim and will of man. The most powerful influence in spreading and sustaining this view of man's relationship to the animal kingdom has been the Old Testament teaching set out in the Book of Moses in Genesis 26, in which it is written, "And God said, let us make man in our own image, after our likeness; and let them have dominion over 
the fish of the sea, and over the fowl of the air, and over the cattle, and over all of the earth, and over every creeping thing that creepeth upon the earth." And as if to rub the message in, the injunction is repeated in the next but one paragraph 28, even more strongly than in 26, "And God blessed them, and God said unto them. Be fruitful and multiply, and replenish the earth, and subdue it: and have dominion over the fish of the sea, and over the fowl of the air, and over every living thing that moveth upon the earth."

These injunctions from God himself, perhaps more than anything else, have contributed to the appaling view that it is man's God-given right to prevail over all other creatures. This homocentric view has given him license, not only in relation to other animals but also to himself, to execute the divine will first by following the philosophy of the cancer cell in multiplying by thoughtless and uninhibited reproduction, second by subduing and devastating the earth, and third by inflicting upon other living creatures the cruelest pains, unspeakable tortures, and death, in the name of husbandry, food, trade, sport, hunting, science, medicine, yes, and even in the name of humanity. Civilized man has already exterminated hundreds of species. In justification of such practices the most transparent insupportable rationalizations have been adduced: animals have no feelings, or at least they are much less sensitive to pain and fatigue than humans, lobsters may be dropped into a cauldron of boiling water because they are only lobsters, and one wouldn't want to eat a live lobster, for that would be uncivilized, not to mention unpalatable. I have heard women and fishermen claim that fish have no feelings, and I have heard all sorts of explanations of this kind offered in support of all the depredations that man has visited upon the animals. And when I say man, I mean socalled "civilized" man, for from the blanket indictment must be exempted virtually all so-called "primitive" peoples, for among them there is reverence and affection for animals and for the environment, of which they consider themselves an intimate part. The creation myths of these people contain no "racist" reflection upon the plant and animal life, or upon the earth which they inhabit. Indeed, quite the contrary. Through their creation myths, these peoples are aware that all things in this natural world are related, and that the various forms they exhibit are merely different expressions of the same original creative materials. Such myths are often extremely beautiful and intelligent, providing a complete account of the origin and even evolution of all things. This is clearly to be observed in the totemic relationships with which different clan members are associated, not only with animal forms but with the sky, the clouds, water holes, rocks, plants, and the like. Among some indigenous peoples, the totemic object is not merely regarded as kin, but is identified with oneself, or else that a vital part of oneself is also an intrinsic part of the revered object, whether plant, animal, or other object (Frazer 1935).

Listen to Jamake Highwater, America Indian and distinguished scholar, who was born and raised on the Blackfeet Blood Reserve in northern Montana. He begins by saying that as he learned English and compared it with the 
language in which he had been raised, he came to realize that "languages are not just different words for the same things but totally different concepts, totally different ways of experiencing and looking at the world.

"As artists have always known, reality depends entirely on how you see things. I grew up in a place that was called a wilderness, but I could never understand how that amazing ecological park could be called 'wilderness,' something wild that needs to be harnessed. Nature is some sort of foe, some sort of adversary in the dominant culture's mentality. We are not part of nature in this society: we are created above it, outside of it, and feel that we must dominate and change it before we can be comfortable and safe within it. I grew up in a culture that considers us literally a part of the entire process that is called nature, to such an extent that when Black Elk called himself brother of the bear, he was quite serious. In other words, Indians did not need Darwin to find out that they were part of nature.

"I saw my first wilderness, as I recall, one August day when I got off a Greyhound bus in a city called New York. Now that struck me as being fairly wild and pretty much out of hand. But I did not understand how the term could be applied to the place where I was from" (Highwater 1982).

The care bestowed upon animals in indigenous cultures, is among the most engaging of their qualities. Pets sleep together with the family, and small animals are often breast fed by the women. The first animal to have been domesticated appears to have been the dog, during the Mesolithic, some 12,000 years ago. The indigenous peoples of the earth appear to have lived by a view of their relationship with it, which is, except for the first paragraph, encapsulated in Job 12: 6-9:

The tabernacles of the robbers prosper, and they that provoke God are secure; into whose hand God bringeth abundantly.

But ask now the beasts, and they shall teach thee; and the fowls of the air, and they shall tell thee:

Or speak to the earth,and it shall teach thee: and the fishes of the sea shall declare unto thee.

Who knoweth not that the hand of the Lord hath wrought this?

In whose hand is the soul of every living thing, and the breath of all mankind.

Note how Job here contrasts the corrupt ways of man with the lessons we have to learn from both animate and inanimate nature.

A similar passage occurs in the Koran, the sacred scripture of Islam, compiled during the seventh century A.D., in which it is written that "There is no beast on earth nor fowl that flieth, but the same are a people like unto you, and to God they shall return."

Is not that a beautiful sentiment? Both the passage from Job and that from the Koran recognize the profound kinship of animals with humans, an appreciation which is not achieved again until the appearance of St. Francis of Assisi in the twelfth century. The combined austerity and poetic gentleness of St. Francis, his vow of poverty, and his love for all living creatures, addressing 
them as brothers and sisters, and so regarding them, introduced a new dimension into the perception of man's relation to other creatures. Through the religious Order which he founded, the Franciscan example and teaching was carried throughout Europe. That St. Francis saw no essential difference between himself and other creatures is illustrated by his words to the wild turtledoves, whom he liberated from the complaisant hands of the youth who had captured them. "O my sisters, simple-minded turtledoves, innocent and chaste, why have ye let yourselves be caught. Now would I fain deliver you from death and make you nests that you may be fruitful and multiply, according to the commandments of your Creator." Here St. Francis views the commandment to increase and multiply as applying to all living creatures, and sees them only as different people unto himself.

It is of interest, in passing, to note, that when I consulted several encyclopedias in order to refresh myself on the life and work of St. Francis, I could find adequate biographical accounts of him but no mention whatever of his profound sense of brotherhood with beast and bird. A somewhat inadequate exception is Julien Green's book (1985) on St. Francis. This, surely, tells us something concerning the interest of contemporary man in our relation to animals. Even the 53 pages devoted to animals in Hastings' great Encyclopaedia of Religion and Ethics omits any reference to man's ethical relationship to animals. Indeed, the only article in that eminent work which discusses the subject is by Henry Salt, the author of the famous Animal Rights, which was published in 1905. Salt's article was devoted to "Humanitarianism," and being the pioneering humanitarian that he was, pays handsome tribute to St. Francis (Salt 1923).

Christianity played a dominant role, especially early Christianity, in the perpetuation of the callous indifference to the fate of animals, for since animals were withoui souls, they were beyond the pale of hope, and at the same time beyond the pale of sympathy. The one outstanding exception to this was the extraordinary St. Chrysostom (A.D. 347-407), who wrote that we should show animals "great kindness and gentleness for many reasons, but above all because they are of the same origins as ourselves." During the Middle Ages, the indifference of the Catholic Church to the claims of animals was broken only by the eccentric example of St. Francis. It is not for nothing that to this day the gentle Buddhists speak of Christendom as "the hell of animals." And it is an object-lesson in humanitarianism to watch a Buddhist gently remove an ant from the hem of his robe, and carefully place it out of harm's way (Pallis 1940).

It is with the Renaissance and the revival of humane learning that we find humane sentiments making their appearance in the writings of such men as Thomas More, Erasmus, Montaigne, Bacon,and others, thus opening the way for the fuller development of humane sentiments which occurred in the eighteenth century in the writings of such authors as Voltaire, Thomson, Pope, Goldsmith, Goethe, Herder, Blake, Burns, and many others. 
It was not until the beginning of the second half of the nineteenth century with the development of experimental studies on animals in the name of physiology, medicine, and what was called vivisection, that the outcry against the mistreatment of animals began to find its voice. This movement acquired increasingly greater momentum during the twentieth century. With the rise of modern experimental medicine and industrial testing chiefly for cosmetics, involving the sacrifice of millions of animals each year, the public and legislatures have become involved as never before. There are today more organizations devoted to the rights and protection of animals than there have ever been, and with the power of these agencies, the future for humanitarianism, even in this conservative age, would seem to be assured. But this would be a dangerous posture to adopt, for in the matter of the rights of animals, like liberty, eternal vigilance is necessary.

What I have been hoping to do in this talk is to provide the scientific basis for the biological kinship of humans with other animals in particular and the whole of nature in general, and to show that the ethical perspective to which such a demonstration leads is inherent in the very nature of nature, that cooperation, love, not conflict and aggression, as we have long been led to believe, is the dominant principle by which living creatures are designed to live with each other. It was not Darwin, but the muscular Darwinists, like Herbert Spencer, who wasn't a biologist at all, but a desk philosopher, who coined the term, "the survival of the fittest," a misnomer which Darwin unfortunately adopted, but later regretted. The term, as we have better come to understand the facts, was a blunder, for it is the "fit" who are most likely to survive, not the "fittest," for the fittest are likely to be overspecialized, where flexibility, adaptability, is required.

In spite of what many of us in the Western world believe, it is not "Nature, red in tooth and claw," as Tennyson sung, that is the law of nature, but cooperation. In spite of sone superficial appearances compounded by their misinterpretation, animals live in a state of cooperation with each other, in the miscalled "wild," yes, even the lion with the gazelle. Of course, some animals eat others, but not because they are in conflict with them or because they dislike them, but rather because they like them. When a lion (usually the lioness) hunts and brings her kill back to her family, it is precisely as when a woman goes shopping, and has nothing to do whatever with aggression or hostility. Lions live in perfect balance and harmony with their environment, serving a very real purpose in the balanced maintenance of the very populations from which they cull their food (Montagu 1949, 1955, 1976).

The facts have never been more soundly stated than by J. Arthur Thomson and Patrick Geddes in their monumental work, Life: Outlines of General Biology, published in 1931, and which did for biology what H.G. Wells' 1922 Outtine of History did for the story of civilization. This is what they wrote:

What has got into circulation is a caricature of Nature-an exaggeration of part of the truth. For while there is in wild Nature much stern shifting, great infantile 
and juvenile mortality, much redness of tooth and claw, and-even outside of parasitism - a general condemnation of the unlit lamp and the ungirt loin, there is much more. In face of limitations and difficulties, one organism intensifies competition, but another increases paternal care; one sharpens its weapons, but another makes some experiments in mutual aid; one thickens its armour, but another triumphs by kin-sympathy. It is realized by few how much of the time and energy of living creatures is devoted to activities which are not to the advantage of the individual, but only to that of the race. Not that this is deliberate altruistic foresight, it is rather that in the course of Nature's tactics survival and success have rewarded not only the strong and self-assertive, but also - and yet more - the loving and self-forgetful. Especially among the finer types, part of the fitness of the survivors has been their capacity for self-sacrifice... The fact is that the struggle for existence need not be competitive at all; it is illustrated not only by all the endeavours of parents for offspring, of mate for mate, of kin for kin. The world is not only the abode of the strong, it is also the home of the loving.

(Thomson and Geddes 1931)

The myths we have created concerning the violence of life in the "wild," "the jungle," and "innate depravity," become the rationalizations for the justification of our attitudes toward animals, and the maintenance of our indifference to their suffering. Our attitudes toward animals are as unnatural as our cities, which are, in fact, the only real jungles. The most shocking thing is that not only do we have the most erroneous views about animals, but in our unwillingness to face the conditions of life for so many in our cities, we project the unsavory image of them upon the screen of Nature, and call it and its inhabitants, the animals, by names which far more accurately apply to us than to them. The fact is that we do not descend from something we wouldn't like to meet in a forest at night, but rather that something descends from us we would not care to meet in broad daylight on a crowded city street.

The Order of animals to which we belong, the Primates, has spent some 60 million years living in forests. Forest-dwelling animals are predominantly vegetarian, and vegetarians have long intestinal tracts - all 22 feet of them. This strongly suggests that we are designed to be vegetarian. It also suggests that many of our ills maybe due to our meat-eating habits.

Our biological ancestry indicates, in brief, that we are programmed to live in peace and harmony with the whole of Nature, and most especially, with all living creatures, that it is more than an ethical necessity-it is a biological imperative if we are to survive. As Albert Schweitzer put it, "Until man extends the circle of his compassion to all living things, man will not himself find peace" (Schweitzer 1934).

The discovery of agriculture some 12,000 years ago lead to the first village settlements and also to the control of animal reproduction. This was followed by the development of cities and theocratic government, with all their attenclant evils, and the dehumanization and exploitation of both man and animals (Childe 1962). Looking back, it would seem that civilization has a natural 
resistance against improving itself. But let us not despair. I believe that the rehumanization of man may follow upon the rehumanization of his attitudes toward animals, and from that, I believe, will follow the repudiation of his xenophobia and the rehumanization of his attitudes toward his fellow man.

I am old enough to recall the days when, some three-quarters of a century ago, antivivisectionists, members of groups for the protection and against cruelty to animals, protesters against fox hunting, and poets like William Blake, who wrote, "A robin redbreast in a cage/ Puts all Heaven in a rage," and "A dog starv'd at his master's gate/ Predicts the ruin of the state," led to nothing but ridicule and derision. Such persons and their supporters were bracketed, in the open scorn for whom it was the fashion to indulge, with suffragettes, conscientious objectors, and other "oddballs." As always, fashion is what people follow who have no taste or minds of their own. But behold, in Switzerland, that most conservative of countries, women have just been granted the vote, so there is hope for humanity yet, even though in the United States it is not uncommon to hear such epithets as "bleeding hearts," "secular humanists," and "liberals," applied with contempt to those who plead the cause of humanity, of humanitarianism. But that, too, will pass, though it will only do so when genuine education, a humane education embracing the whole of nature, will have become the birthright of every citizen.

I see no other possibility in a free society of ensuring the growth and development of personalities who are able to think for themselves and to feel that compassion for all living creatures, for the whole of nature, that will ensure equal freedom for growth and development. I would therefore like to devote my final remarks to what I consider education to be.

Let me say at once that $\mathbb{l}$ do not think that genuine education exists anywhere in the Western world. What we call education is nothing but instruction, a training in techniques and skills. Whatever we teach we tend to teach as a kind of technology, in which we emphasize the structure of things in order to be able to put what we learn to practical use. Because our schools, colleges, and universities are locked into an outmoded form of thinking about what human beings are for, and about their place in nature, and because what they produce are for the most part stereotypers, the lovers of ritual incantation, who have never been taught that a word should ask itself what it means, and that the meaning of a word is the action it produces, that the world is in the sorry state it is, and that it is principally for these reasons that the world and that the attitudes of people toward animals are what they are.

In spite of the age-old dissociation between thinking and feeling, thinking and feeling are reciprocally indissolubly interrelated, and that, indeed, is what they are designed to be. Without for a moment slighting the prenatal period (Montagu 1962, 1978), what we need to understand is that education begins at birth, and that it is from that critical period on that we must revise our approaches to the child who, at the present time we continue to deform in such wrongheaded ways, and continue to do so for the rest of its life, so that 
we may truly describe most adults as nothing more or less than deteriorated infants, for most individuals have been failed in the education, the satisfaction and fulfillment of their potentialities as healthy human beings (Montagu 1981).

As a consequence of the confusion into which we have fallen as a result of our miseducation, we stand very near the brink of self-annihilation. It was no less a thinker than H.G. Wells who, in 1922, twenty-four years before his death, wrote in his widely read Outline of History, what is today even more than ever ominously true, that "Human history becomes more and more a race between education and catastrophe."

The hour is, indeed, late - it is therefore critically necessary for us to recognize that because we are human beings,and because we are capable of shedding our errors, that we are educable, that we need to be educated in humanity beyond everything else, to learn to live as fulfilled human beings, to learn to live as if to live and love were one.

The word "education" is derived from the Latin, educare, which means to nourish and to cause to grow. To nourish and to cause to grow what? The answer to that question,by the measure of all the verifiable evidences is: to nourish and to cause to grow those basic behavioral needs or potentialities with which every newborn is endowed, the needs for love, sensitivity, friendship, speech, thinking, to know, to learn, to organize, to work, for curiosity, wonder, play, creativity, imagination, open mindedness, experimental-mindedness, explorativeness, resiliency, humor, joy, laughter, tears, optimism, honesty, trust, compassionate intelligence, dance, song, enthusiasm, touch, and others.

These are the basic behavioral needs the development of which must be encouraged by caregivers throughout the life of the young, if they are to grow into healthy human beings. By a healthy human being I mean one who is able to love, to work, to play, and to use one's mind critically. It is not possible to define all these terms here. I have done so elsewhere (Montagu 1981). It is imperative for us to always bear these basic behavioral needs in mind, and to implement them by sound strategies.

Finally, I would like to conclude with the words of Henry G. Maurice, from a lecture he delivered in Brussels in 1946, and published in English in 1948 , in the summer of which I read it,and which has since inspired my thinking on the subjects of humanity's relation to animals.

"To understand man," wrote Maurice, "one must study him in the light of the ecology within which he has been developed and of which he is an integral part. I give no pledge that this study will reveal to us a remedy for the ills that man has brought upon himself, but I am not afraid to assert that we can never understand man and the problems which afflict him until we have learned to appreciate the ties which link man to his fellow creatures. As we pursue the study of this relationship we cannot fail to admire the wonders and beauties of Nature, and, as we compare the behavior of men with that of the beasts we may begin to understand that those whom, in our insolence, we call the lower' animals can teach us many lessons of tolerance 
and good will. And, for my part, I can envisage the possibility that, stifled as we are by the atmosphere of despair that has invaded the world, and crushed by the misfortunes engendered thereby, the contemplation of the harmonious equilibrium and the regularly renewed beauties of Nature may renew and strengthen in our hearts the hope that is well nigh dead, and that with renewed hope may come that humility which is the beginning and the hallmark of true wisdom" (Maurice 1948).

\section{Endnotes}

${ }^{\mathbf{1}}$ Keynote Address: Presented at the national conference, "Animals and Humans: Ethical Perspectives," Moorhead State University, Moorhead, MN, April 21-23, 1986.

2321 Cherry Hill Rd, Princeton, NJ 08540.

\section{References}

Childe, VG. 1962. Man Makes Himself. New York: New American University.

Frazer, JG. 1935. Creation and Evolution in Primitive Cosmogonies. London: Macmillan.

Gilbert, M. 1981. Auschwitz and the Allies: New York: Holt, Rinehart and Winston.

-. 1986. The Holocaust. New York: Rinehart and Winston.

Green, J. 1985. God's Fool: The Life and Times of Francis of Assisi. New York: Harper and Row.

Highwater, J. 1982. As native Americans percelve the world. In: Schwartz, M. ed. TV and Teenz: Reading, MA: AddisonWesley.

Maurice, HG. 1948. Ask Now the Beasts. London: Sociey for the Preservation of Fauna of the Empire.

Montagu, A. 1949. The origin and nature of social life and the biological basis of cooperation. J. Soc. Psychol. 29: $267-83$.

-. 1955. The Direction of Haman Development. New Yoik: Harper Bros

-. 1960a. Why man weeps. Think. 26: 7-9.

-. 1960b. Why man laughs. Think 26: 30-32.

--. 1962. Prenatal Influences. Springfield, IL: C.C. Thonas.

- 1974. Man's Most Dangorous Myth: The Fallacy of Race. Fifth ed. New Yort: Oxford Uni versity Press

-. 1976. The Nature of Human Aggression. New York: Oxford University Press.

- 1978. Life Before Birtb. New York: New American University.

-. 1981. Growing Young. New York: MoGraw-Hill

-. 1984. (editor). Science and Creationisn. New York: Oxford University Press.

Pallis, M. 1940. Peaks and Lamas. New York: Knopf.

Ross, RW. 1980. So It Was True: The American Prostestant Press and the Nazt Persecution of the Jews. Minneapolis, MN: Univ. of Minnesota Press.

Salt, HS. 1923. Humanitarianism. In: Hastings, \}. ed. Encyclopaedia of Religion and Etbics. 6: 836-40.

Schweitzer, A. 1934. The Philosoplyy of Civilization. London: A. and C. Black.

Thomson, JA and Geddes, P. 1931. Life: Outlines of General Biology? New York: Harper and Bros.

Wells, HG. 1922. Outline of History. New York: Macmillan.

Wyman, DS. 1984. The Abandonment of the Jeus. New York: Pantheon Books.

- 1985. Paper Walls. New York: Pantheon Books. 